УДК 502.4:597.6+598.1

И. Н. Залипуха, А. Н. Мисюра, А. А. Марченковская

Днепропетровский начиональный университет им. Олеся Гончара

\title{
БИОХИМИЧЕСКИЕ ПОКАЗАТЕЛИ АМФИБИЙ ИЗ ВОДОЕМОВ С РАЗЛИЧНЫМ УРОВНЕМ ПОСТУПЛЕНИЯ ОТХОДОВ УРАНОДОБЫВАЮЩЕЙ ПРОМЫШЛЕННОСТИ
}

Досліджено вплив відходів підприсмств із видобування та переробки уранової руди на параметри метаболізму фонового виду амфібій Придніпровського регіону - озерної жаби (Реlophylax ridibundus). Встановлено зміну вмісту в органах і тканинах тварин білка, ліпідів і вуглеводів із віком, а також зменшення цих біохімічних параметрів організму тварин залежно від ступеня впливу забруднення. Значне збільшення витрачання енергії запасних енергетичних речовин (ліпідів і вуглеводів) один із механізмів біохімічної адаптації, що сприяє частковій резистентності амфібій в умовах впливу відходів підприємств цього виду гірничодобувної промисловості.

I. N. Zalipuha, A. N. Misyura, A. A. Marchenkovskaya

Oles’ Gonchar Dnipropetrovsk National University

\section{AMPHIBIANS BIOCHEMICAL INDICES FROM RESERVOIRS OF DIFFERENT LEVELS OF WASTE DISCHARGE}

Influence of uranium mining and processing wastes on the metabolism of common amphibian species of the Dnieper region - the marsh frog (Pelophylax ridibundus) - from differently contaminated reservoirs. The change of protein, lipids and carbohydrates in organs and tissues of frogs with ageing and under influence of the pollution. Considerable increase of energy consumption at the expense of lipids and carbohydrates is one of biochemical adaptations. It promotes partial resistance of amphibians to the influence of uranium mining wastes.

\section{Введение}

Интенсивное развитие промышленного комплекса привело к обострению экологической ситуации в Приднепровском регионе и, в частности, в Днепропетровской области, относящейся ко второму классу химической опасности [4]. Связано это, прежде всего, с концентрацией промышленного производства и, в первую очередь, горнодобывающей, металлургической, химической и машиностроительной отраслями. На территории области функционирует свыше 500 промышленных объектов, 40 железорудных и угольных шахт, крупнейшие в стране горнодобывающие и металлургические комбинаты, химические и машиностроительные предприятия. Территориальная концентрация промышленного потенциала превышает в два раза средний уровень по Украине. Ежегодно в окружающую среду области поступает 49718 млн. т вредных веществ [4]. Более 3 млрд. м $^{3}$ жидких и твердых отходов аккумулируется в хвостохранилищах, отстойниках, шлаконакопителях, отвалах, что обуславливает загрязнение поверхностных и подземных вод токсическими соединениями. В поверхностные воды области сбрасывается

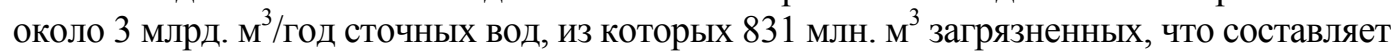


36 \% объема загрязненных вод всей Украины [1]. Распределение техногенных нагрузок по районам и городам области неравномерно. В наиболее кризисной экологической ситуации находятся Кривбасс, Западный Донбасс, Пятихатский, Верхнеднепровский, Никопольский районы, а также города Желтые Воды, Вольногорск, Никополь, Днепродзержинск и Днепропетровск. В составе отходов содержатся токсичные вещества, из которых приоритетные для региона - тяжелые металлы, нефтепродукты, пестициды, СПАВ, фенолы, ароматические углеводородные соединения, радиоактивные изотопы. Попадая в окружающую среду, токсиканты образуют метаболиты, высокоактивные соединения, характер воздействия которых на живые организмы не изучен. Между тем, включаясь в биогеохимические циклы по трофическим цепям, в процессе дыхания они попадают в организм животных и вызывают нарушения метаболизма [8-10].

В связи с вышеуказанным, целью данной работы являлась оценка влияния отходов предприятий по добыче и переработке урановой руды на параметры метаболизма фонового вида амфибий Приднепровского региона - озерной лягушки (Pelophylax ridibundus) из водоемов различной степени загрязнения отходами этих предприятий.

\section{Материал и методы исследований}

Амфибий отбирали для исследований в четырех водоемах на территории г. Желтые Воды и в прилегающих биотопах: р. Желтая, водоем городского парка, водоем хвостохранилища неработающей шахты Ольховская (Т) и водоем хвостохранилища шахты Новая Северного горнообогатительного комбината (СевГОКа) - (Р). Исследование параметров метаболизма амфибий проведено на одновозрастных животных, отобранных методом неизбирательного отлова в сумеречное и ночное время суток при помощи подсветки фонарем. Производился общебиологический анализ животных. Определялись размерные показатели с точностью до 0,01 см и масса тела с точностью до 0,001 г. Возраст амфибий определялися по методике Э. М. Смириной [2; 7]. Подготовка проб для определения белка, липидов и гликогена производилась по стандартным методикам [3; 5; 6] с последующим анализом полученного материала спектрофотометрическим методом на двухлучевом спектрофотометре Specord M-40 фирмы Карл Цейс Йена (Германия).

\section{Результаты и их обсуждение}

Исследование воды водоемов из мест обитания амфибий показало содержание в ней значительного количества как биогенных (железо, марганец, медь, цинк, никель), так и токсичных (свинец и кадмий) микроэлементов. Все исследуемые микроэлементы по степени снижения их содержания в воде водоемов можно расположить в следующем порядке: железо, свинец, цинк, никель, марганец, медь, кадмий. Кроме них в состав воды входят их радиоактивные изотопы, что особенно часто наблюдается в хвостохранилищах шахтных вод (табл. 1). Сравнительный анализ содержания тяжелых металлов в воде исследуемых водоемов показал, что наименьшее количество всех исследуемых элементов содержится в воде р. Желтая, которую можно отнести к «условно чистой» для данной территории. Остальные три исследуемых водоема по степени увеличения в составе воды микроэлементов можно расположить в следующем порядке: водоем городского парка, водоем хвостохранилища Т отработанной шахты Ольховская и водоем хвостохранилища Р шахты Новая.

Содержание белка в органах и тканях озерной лягушки из биотопов р. Желтая наиболее высоко в селезенке сеголеток, за которой по степени снижения располагаются почки, легкие, кожа, печень, сердце, мышцы (табл. 2). При этом показатели животных имеют сравнительно низкие коэффициенты вариации, уровень которых также на- 
иболее высок для показателей содержания белка в селезенке, легких и коже. Для остальных органов и тканей, кроме мышц, эти показатели находятся на одном уровне.

Таблица 1

Содержание микроэлементов (мг/л) в водоемах Приднепровского региона

с разной степенью загрязнения

\begin{tabular}{|l|c|c|c|c|c|c|c|}
\hline \multirow{2}{*}{ Водоемы } & \multicolumn{7}{|c|}{ Микроэлементы } \\
\cline { 2 - 8 } & $\mathrm{Fe}$ & $\mathrm{Mn}$ & $\mathrm{Cu}$ & $\mathrm{Zn}$ & $\mathrm{Ni}$ & $\mathrm{Pb}$ & $\mathrm{Cd}$ \\
\hline р. Желтая & $58,29 \pm 5,18$ & $1,82 \pm 1,24$ & $1,92 \pm 0,17$ & $12,55 \pm 1,84$ & $8,25 \pm 1,18$ & $16,84 \pm 2,46$ & $2,10 \pm 0,32$ \\
\hline Городской парк & $46,17 \pm 3,98$ & $2,14 \pm 0,86$ & $1,15 \pm 0,19$ & $6,21 \pm 0,44$ & $4,15 \pm 0,83$ & $10,71 \pm 2,12$ & $1,46 \pm 0,84$ \\
\hline $\begin{array}{l}\text { Хвостохранилище Т } \\
\text { шахты Ольховская }\end{array}$ & $65,92 \pm 6,18$ & $5,61 \pm 0,75$ & $2,05 \pm 0,34$ & $32,17 \pm 4,82$ & $8,45 \pm 1,16$ & $21,00 \pm 2,32$ & $2,84 \pm 0,59$ \\
\hline $\begin{array}{l}\text { Хвостохранилище } \mathrm{P} \\
\text { шахты Новая }\end{array}$ & $59,01 \pm 6,71$ & $7,71 \pm 0,84$ & $9,54 \pm 0,72$ & $15,77 \pm 2,41$ & $10,43 \pm 1,12$ & $30,51 \pm 3,12$ & $8,52 \pm 0,97$ \\
\hline
\end{tabular}

Биохимические параметры органов и тканей озерной лягушки

Таблица 2 из биотопов р. Желтая (\% м. массы)

\begin{tabular}{|c|c|c|c|c|c|c|c|c|c|c|}
\hline \multirow{2}{*}{\begin{tabular}{|l|} 
Bo3- \\
pact
\end{tabular}} & \multirow{2}{*}{$\begin{array}{c}\text { Биохимические } \\
\text { параметры }\end{array}$} & \multirow{2}{*}{$\begin{array}{l}\text { Пока- } \\
\text { затели }\end{array}$} & \multicolumn{8}{|c|}{ Органы и ткани } \\
\hline & & & печень & почки & сердце & легкие & селезенка & мышщы & гонады & кожа \\
\hline \multirow{6}{*}{$0+$} & \multirow[t]{2}{*}{ белок } & $x \pm m$ & $\begin{array}{c}8,28 \pm \\
0,12 \\
\end{array}$ & $\begin{array}{c}12,18 \pm \\
1,20 \\
\end{array}$ & $\begin{array}{c}8,16 \pm \\
1,40 \\
\end{array}$ & $\begin{array}{c}10,16 \pm \\
1,56 \\
\end{array}$ & $\begin{array}{c}28,60 \pm \\
6,58 \\
\end{array}$ & $\begin{array}{c}8,15 \pm \\
0,68\end{array}$ & - & $\begin{array}{c}10,07 \pm \\
2,15 \\
\end{array}$ \\
\hline & & $C_{v}$ & 46,17 & 48,41 & 48,56 & 54,72 & 58,90 & 26,59 & - & 52,17 \\
\hline & \multirow[t]{2}{*}{ липиды } & $x \pm m$ & $\begin{array}{c}3,45 \pm \\
0,42 \\
\end{array}$ & $\begin{array}{c}8,25 \pm \\
0,32 \\
\end{array}$ & $\begin{array}{c}6,50 \pm \\
0,30 \\
\end{array}$ & $\begin{array}{c}6,88 \pm \\
0,92 \\
\end{array}$ & $\begin{array}{c}4,18 \pm \\
0,30 \\
\end{array}$ & $\begin{array}{c}2,70 \pm \\
0,16 \\
\end{array}$ & - & $2,40 \pm 0,12$ \\
\hline & & $C_{v}$ & 23,82 & 38,50 & 30,52 & 40,58 & 48,40 & 20,52 & - & 40,18 \\
\hline & \multirow[t]{2}{*}{ гликоген } & $x \pm m$ & $\begin{array}{c}210,20 \pm \\
40,22\end{array}$ & - & - & - & - & $\begin{array}{c}20,18 \pm \\
4,17\end{array}$ & - & $\begin{array}{c}33,40 \pm \\
4,20\end{array}$ \\
\hline & & $C_{v}$ & 39,18 & - & - & - & - & 52,40 & - & 50,18 \\
\hline \multirow{6}{*}{$1-2+$} & \multirow[t]{2}{*}{ белок } & $x \pm m$ & $\begin{array}{c}10,40 \pm \\
0,26\end{array}$ & $\begin{array}{c}14,96 \pm \\
2,18 \\
\end{array}$ & $\begin{array}{c}8,92 \pm \\
0,92 \\
\end{array}$ & $\begin{array}{c}10,92 \pm \\
0,48 \\
\end{array}$ & $\begin{array}{c}29,12 \pm \\
1,56 \\
\end{array}$ & $\begin{array}{c}8,90 \pm \\
3,12 \\
\end{array}$ & $8,0 \pm 2,60$ & $\begin{array}{c}10,80 \pm \\
0,14 \\
\end{array}$ \\
\hline & & $C_{v}$ & 44,20 & 32,52 & 30,70 & 32,18 & 52,70 & 32,90 & 32,40 & 24,17 \\
\hline & \multirow[t]{2}{*}{ липиды } & $x \pm m$ & $\begin{array}{c}3,90 \pm \\
0,40\end{array}$ & $\begin{array}{c}8,92 \pm \\
0,58 \\
\end{array}$ & $\begin{array}{c}11,26 \pm \\
3,18 \\
\end{array}$ & $\begin{array}{c}5,98 \pm \\
0,86 \\
\end{array}$ & $\begin{array}{c}4,92 \pm \\
0,28\end{array}$ & $\begin{array}{c}2,58 \pm \\
0,20\end{array}$ & $\begin{array}{c}5,90 \pm \\
1,68 \\
\end{array}$ & $2,28 \pm 0,18$ \\
\hline & & $C_{v}$ & 30,54 & 32,16 & 33,60 & 42,18 & 50,70 & 43,60 & 44,18 & 43,21 \\
\hline & \multirow[t]{2}{*}{ гликоген } & $x \pm m$ & $\begin{array}{c}220,20 \pm \\
42,18\end{array}$ & - & - & - & - & $\begin{array}{c}25,90 \pm \\
5,20\end{array}$ & - & $\begin{array}{c}34,90 \pm \\
3,90\end{array}$ \\
\hline & & $C_{v}$ & 52,60 & - & - & - & - & 55,80 & - & 49,90 \\
\hline \multirow{6}{*}{$3-4+$} & \multirow[t]{2}{*}{ белок } & $x \pm m$ & $\begin{array}{c}10,80 \pm \\
0,72 \\
\end{array}$ & $\begin{array}{c}15,08 \pm \\
1,65 \\
\end{array}$ & $\begin{array}{c}9,90 \pm \\
1,92 \\
\end{array}$ & $\begin{array}{c}10,58 \pm \\
3,16 \\
\end{array}$ & $\begin{array}{c}30,60 \pm \\
2,18 \\
\end{array}$ & $\begin{array}{c}9,20 \pm \\
2,94 \\
\end{array}$ & $\begin{array}{c}12,92 \pm \\
1,90 \\
\end{array}$ & $\begin{array}{c}11,70 \pm \\
1,14 \\
\end{array}$ \\
\hline & & $C_{v}$ & 30,56 & 36,92 & 45,16 & 40,60 & 58,90 & 28,40 & 48,54 & 22,70 \\
\hline & \multirow[t]{2}{*}{ липиды } & $x \pm m$ & $\begin{array}{c}2,50 \pm \\
0,40\end{array}$ & $\begin{array}{c}6,80 \pm \\
1,34 \\
\end{array}$ & $\begin{array}{c}10,15 \pm \\
2,40\end{array}$ & $\begin{array}{c}4,90 \pm \\
0,48\end{array}$ & $\begin{array}{c}, 86 \pm \\
0,32 \\
\end{array}$ & $\begin{array}{c}2,20 \pm \\
0,16\end{array}$ & $\begin{array}{c}6,40 \pm \\
3,25\end{array}$ & $\begin{array}{c}2,16 \pm \\
0,16\end{array}$ \\
\hline & & $C_{v}$ & 32,16 & 36,93 & 38,62 & 43,15 & 52,98 & 40,14 & 48,14 & 40,25 \\
\hline & \multirow[t]{2}{*}{ гликоген } & $x \pm m$ & $\begin{array}{c}220,80 \pm \\
26,90 \\
\end{array}$ & - & - & - & - & $\begin{array}{c}24,18 \pm \\
4,30 \\
\end{array}$ & - & $\begin{array}{c}37,80 \pm \\
4,90 \\
\end{array}$ \\
\hline & & $C_{v}$ & 40,30 & - & - & - & - & 69,30 & - & 68,30 \\
\hline \multirow{6}{*}{$5-6$} & \multirow[t]{2}{*}{ белок } & $x \pm m$ & $\begin{array}{c}10,20 \pm \\
2,28\end{array}$ & $\begin{array}{c}15,22 \pm \\
3,17 \\
\end{array}$ & $\begin{array}{c}10,02 \pm \\
1,56 \\
\end{array}$ & $\begin{array}{c}12,98 \pm \\
2,70 \\
\end{array}$ & $\begin{array}{c}32,96 \pm \\
4,18\end{array}$ & $\begin{array}{c}9,18 \pm \\
3,16\end{array}$ & $\begin{array}{c}14,70 \pm \\
3,16\end{array}$ & $\begin{array}{c}12,58 \pm \\
2,90\end{array}$ \\
\hline & & $C_{v}$ & 28,15 & 42,80 & 42,18 & 42,96 & 50,16 & 30,15 & 52,14 & 29,34 \\
\hline & \multirow[t]{2}{*}{ липиды } & $x \pm m$ & $\begin{array}{c}3,40 \pm \\
0,42\end{array}$ & $\begin{array}{c}6,90 \pm \\
0,62 \\
\end{array}$ & $\begin{array}{c}8,40 \pm \\
1,26\end{array}$ & $\begin{array}{c}5,40 \pm \\
0,38\end{array}$ & $\begin{array}{c}5,90 \pm \\
0,12\end{array}$ & $\begin{array}{c}2,98 \pm \\
0,12\end{array}$ & $\begin{array}{c}7,42 \pm \\
0,56\end{array}$ & $1,98 \pm 0,72$ \\
\hline & & $C_{v}$ & 32,42 & 40,82 & 38,20 & 40,28 & 44,55 & 28,70 & 46,46 & 40,20 \\
\hline & \multirow[t]{2}{*}{ гликоген } & $x \pm m$ & $\begin{array}{c}228,90 \pm \\
15,90\end{array}$ & - & - & - & - & $\begin{array}{c}42,50 \pm \\
5,70\end{array}$ & - & $\begin{array}{c}45,70 \pm \\
5,40 \\
\end{array}$ \\
\hline & & $C_{v}$ & 42,70 & - & - & - & - & 70,40 & - & 78,70 \\
\hline
\end{tabular}

Показатели липидов наиболее высоки в почках, за которыми по степени снижения следуют сердце, легкие, селезенка, печень, мышечная ткань, кожа. Коэффициенты вариации показателей содержания липидов находятся на еще более низком уровне, по 
сравнению с показателями содержания белка, увеличиваясь для селезенки $(48,4$ \%), легких и кожи (40,6 и 40,2 \% соответственно).

Уровень гликогена исследован в печени, коже и мышцах. Этот показатель наиболее высок в печени, за которой следуют кожа и мышечная ткань. Анализ возрастной динамики исследуемых биохимических параметров показывает, что содержание в органах и тканях белка с возрастом увеличивается как у амфибий 1-2 лет, так и у амфибий 3-4 лет и 5-6 лет, что особенно проявляется в гонадах, селезенке и легких. Коэффициенты вариации содержания белка находятся примерно на одном уровне (табл. 2) у животных 1, 2, 3 и 4 лет, несколько увеличиваясь у амфибий 5-6 лет.

Следует отметить, что уровень липидов у амфибий 3-4 лет немного снижается, что, очевидно, связано с болышими энергетическими затратами организма животных в период интенсивного созревания гонад и начала размножения. У амфибий 5-6 лет этот показатель увеличивается, что свидетельствует об определенной стабилизации уровня метаболизма организма амфибий. Это также подтверждается и изменением содержания гликогена (см. табл. 2). Уровень гликогена у амфибий всех возрастных групп в коже выше по сравнению с его содержанием в мышечной ткани.

Исследования обитающих в р. Желтая амфибий различного возраста выявили, что биохимические показатели животных зависят от возраста амфибий, а также функций белков, липидов и углеводов в органах и тканях животных.

Показатели гликогена в печени характеризуются также наиболее низкими коэффициентами вариации, в то время как максимальные коэффициенты вариации для содержания гликогена установлены в мышечной ткани, где идет его наиболее быстрый синтез и расходование для энергоемких процессов организма.

Биохимические параметры амфибий из второго водоема на территории городского парка находятся на близком уровне, по сравнению с амфибиями из биотопов p. Желтая. Установлено снижение содержания липидов в различных органах и тканях амфибий, кроме селезенки сеголеток. У животных из этого водоема отмечается та же тенденция в изменении биохимических параметров органов и тканей в зависимости от возраста амфибий (как и у амфибий из биотопов р. Желтая). Некоторые изменения этих показателей связаны, очевидно, с миграцией амфибий разного возраста из биотопов р. Желтая, а, возможно, также из водоемов-хвостохранилищ шахтных вод горнодобывающих предприятий.

В водоемах хвостохранилища отработанной шахты Ольховская в популяциях амфибий отсутствуют сеголетки (табл. 4), а также сеголетки и годовики в хвостохранилище Р шахты Новая, что не позволяет сравнить биохимические показатели амфибий этих возрастных групп с животными из биотопов р. Желтая и водоема городского парка (см. табл. 3, 4). Амфибии 1-2 лет из этих биотопов характеризуются более высоким содержанием белка, по сравнению с амфибиями из биотопов, рассмотренных ранее, при более низких показателях липидов и гликогена у амфибий 3-4 лет. У животных 5-6 лет происходит увеличение показателей белка при снижении липидов и гликогена (кроме кожи, печени, селезенки и почек). Это способствует повышению резистентности организма амфибий и определенной степени их адаптации в данных условиях загрязнения среды.

Следует считать, что естественными биохимическими параметрами органов и тканей амфибий являются показатели, установленные у амфибий из биотопов р. Желтая и в определенной степени - амфибий из водоема городского парка, у которых отмечается некоторое снижение содержания в органах и тканях белка и липидов при незначительном увеличении содержания в печени, мышечной ткани и коже гликогена у сеголеток и годовиков амфибий (см. табл. 3). У животных 3-4 лет происходит увели- 
чение содержания белка в почках, сердце, легких и коже, т. е. в органах, тесно связанных со средой обитания и выполняющих в организме важные физиологические функции. В то же время у животных этой возрастной группы наблюдается увеличение в органах и тканях липидов и гликогена, что связано с происходящими в организме перестройками вследствие их миграции из более отдаленных мест обитания, поскольку в продолжение исследований в водоеме не было обнаружено кладок икры и личинок амфибий. Увеличение указанных биохимических параметров органов и тканей установлено также и у амфибий 5-6 лет, у которых происходит определенная адаптация к данным условиям обитания.

Таблича 3

Биохимические параметры органов и тканей озерной лягушки из водоемов городского парка г. Желтые Воды (\% м. массы)

\begin{tabular}{|c|c|c|c|c|c|c|c|c|c|c|}
\hline \multirow{2}{*}{$\begin{array}{l}\text { Воз- } \\
\text { раст }\end{array}$} & \multirow{2}{*}{$\begin{array}{c}\text { Биохимические } \\
\text { параметры }\end{array}$} & \multirow{2}{*}{$\begin{array}{l}\text { Пока- } \\
\text { затели }\end{array}$} & \multicolumn{8}{|c|}{ Органы и ткани } \\
\hline & & & печень & почки & сердце & легкие & селезенка & мышщы & гонады & кожа \\
\hline \multirow{6}{*}{$0+$} & \multirow[t]{2}{*}{ белок } & $x \pm m$ & $8,40 \pm 0,42$ & $\begin{array}{c}12,18 \pm \\
1,72 \\
\end{array}$ & $\begin{array}{c}8,42 \pm \\
1,32 \\
\end{array}$ & $\begin{array}{c}10,72 \pm \\
0,98\end{array}$ & $\begin{array}{c}25,17 \pm \\
3,96\end{array}$ & $7,12 \pm 0,74$ & - & $\begin{array}{c}7,92 \pm \\
1,56 \\
\end{array}$ \\
\hline & & $C_{v}$ & 62,18 & 59,61 & 44,59 & 51,16 & 68,72 & 56,92 & - & 67,28 \\
\hline & \multirow[t]{2}{*}{ липиды } & $x \pm m$ & $2,14 \pm 0,17$ & $\begin{array}{c}6,52 \pm \\
0,73 \\
\end{array}$ & $\begin{array}{c}9,18 \pm \\
1,67 \\
\end{array}$ & $\begin{array}{c}6,02 \pm \\
3,56\end{array}$ & $5,19 \pm 0,33$ & $2,48 \pm 0,14$ & - & $\begin{array}{c}2,26 \pm \\
0,42\end{array}$ \\
\hline & & $C_{v}$ & 49,72 & 39,72 & 50,72 & 47,18 & 59,68 & 32,19 & - & 41,90 \\
\hline & \multirow[t]{2}{*}{ гликоген } & $x \pm m$ & $\begin{array}{c}215,90 \pm \\
20,44 \\
\end{array}$ & - & - & - & - & $2,48 \pm 0,14$ & - & $\begin{array}{c}33,12 \pm \\
4,90\end{array}$ \\
\hline & & $C_{v}$ & 56,90 & - & - & - & - & 50,18 & - & 58,30 \\
\hline \multirow{6}{*}{$1-2+$} & \multirow[t]{2}{*}{ белок } & $x \pm m$ & $8,64 \pm 1,48$ & $\begin{array}{c}14,18 \pm \\
2,06\end{array}$ & $\begin{array}{c}10,18 \pm \\
1,65 \\
\end{array}$ & $\begin{array}{c}10,90 \pm \\
1,30 \\
\end{array}$ & $\begin{array}{c}28,96 \pm \\
2,14\end{array}$ & $9,16 \pm 2,40$ & $\begin{array}{c}9,92 \pm \\
0,52 \\
\end{array}$ & $\begin{array}{c}9,30 \pm \\
1,32 \\
\end{array}$ \\
\hline & & $C_{v}$ & 59,16 & 42,17 & 40,18 & 50,10 & 50,12 & 38,17 & 28,40 & 18,56 \\
\hline & \multirow[t]{2}{*}{ липиды } & $x \pm m$ & $3,80 \pm 0,14$ & $\begin{array}{c}7,19 \pm \\
1,36 \\
\end{array}$ & $\begin{array}{c}10,08 \pm \\
2,44\end{array}$ & $\begin{array}{c}3,98 \pm \\
0,16 \\
\end{array}$ & $3,86 \pm 0,23$ & $1,92 \pm 0,13$ & $\begin{array}{c}3,86 \pm \\
0,97 \\
\end{array}$ & $\begin{array}{c}1,99 \pm \\
0,56 \\
\end{array}$ \\
\hline & & $C_{v}$ & 39,70 & 28,64 & 38,42 & 40,97 & 45,54 & 30,14 & 29,72 & 43,84 \\
\hline & \multirow[t]{2}{*}{ гликоген } & $x \pm m$ & $\begin{array}{c}225,10 \pm \\
10,20 \\
\end{array}$ & - & - & - & - & $\begin{array}{c}28,60 \pm \\
4,80\end{array}$ & - & $\begin{array}{c}40,20 \pm \\
5,80 \\
\end{array}$ \\
\hline & & $\overline{C_{v}}$ & 50,40 & - & - & - & - & 60,18 & - & 58,90 \\
\hline \multirow{6}{*}{$3-4+$} & \multirow[t]{2}{*}{ белок } & $x \pm m$ & $7,08 \pm 1,08$ & $\begin{array}{c}16,02 \pm \\
2,14 \\
\end{array}$ & $\begin{array}{c}11,27 \pm \\
2,14 \\
\end{array}$ & $\begin{array}{c}11,00 \pm \\
1,48 \\
\end{array}$ & $\begin{array}{c}27,08 \pm \\
4,19\end{array}$ & $9,20 \pm 1,62$ & $\begin{array}{c}7,20 \pm \\
0,92 \\
\end{array}$ & $\begin{array}{c}12,30 \pm \\
1,68 \\
\end{array}$ \\
\hline & & $C_{v}$ & 35,18 & 30,72 & 29,77 & 41,16 & 32,16 & 38,70 & 23,14 & 18,92 \\
\hline & \multirow[t]{2}{*}{ липиды } & $x \pm m$ & $3,18 \pm 0,18$ & $\begin{array}{c}8,78 \pm \\
1,12 \\
\end{array}$ & $\begin{array}{c}10,92 \pm \\
0,92 \\
\end{array}$ & $\begin{array}{c}4,98 \pm \\
0,74 \\
\end{array}$ & $5,16 \pm 0,28$ & $2,70 \pm 0,11$ & $\begin{array}{c}6,62 \pm \\
0,38 \\
\end{array}$ & $\begin{array}{c}3,18 \pm \\
0,24\end{array}$ \\
\hline & & $C_{v}$ & 27,16 & 24,16 & 32,70 & 34,92 & 38,72 & 22,76 & 27,50 & 38,16 \\
\hline & \multirow[t]{2}{*}{ гликоген } & $x \pm m$ & $\begin{array}{c}230,20 \pm \\
40,18 \\
\end{array}$ & - & - & - & - & $\begin{array}{c}22,18 \pm \\
1,86 \\
\end{array}$ & - & $\begin{array}{c}40,60 \pm \\
5,90 \\
\end{array}$ \\
\hline & & $C_{v}$ & 48,90 & - & - & - & - & 60,80 & - & 55,80 \\
\hline \multirow{6}{*}{$5-6$} & \multirow[t]{2}{*}{ белок } & $x \pm m$ & $10,96 \pm 2,14$ & $\begin{array}{c}16,87 \pm \\
5,10 \\
\end{array}$ & $\begin{array}{c}9,86 \pm \\
1,80 \\
\end{array}$ & $\begin{array}{c}12,90 \pm \\
2,34 \\
\end{array}$ & $\begin{array}{c}34,96 \pm \\
6,92 \\
\end{array}$ & $7,16 \pm 1,05$ & $\begin{array}{c}12,68 \pm \\
2,34 \\
\end{array}$ & $\begin{array}{c}10,16 \pm \\
2,12 \\
\end{array}$ \\
\hline & & $C_{v}$ & 30,16 & 28,72 & 25,17 & 30,16 & 27,12 & 30,17 & 20,42 & 18,72 \\
\hline & \multirow[t]{2}{*}{ липиды } & $x \pm m$ & $4,00 \pm 0,28$ & $\begin{array}{c}, 12 \pm \\
0,48 \\
\end{array}$ & $\begin{array}{c}6,17 \pm \\
0,62 \\
\end{array}$ & $\begin{array}{c}5,18 \pm \\
0,32 \\
\end{array}$ & $5,80 \pm 0,14$ & $2,08 \pm 0,12$ & $\begin{array}{c}5,40 \pm \\
0,22 \\
\end{array}$ & $\begin{array}{c}3,00 \pm \\
0,10 \\
\end{array}$ \\
\hline & & $C_{v}$ & 29,18 & 28,20 & 30,12 & 31,18 & 30,14 & 20,12 & 20,18 & 30,12 \\
\hline & \multirow[t]{2}{*}{ гликоген } & $x \pm m$ & $\begin{array}{c}235,90 \pm \\
18,60 \\
\end{array}$ & - & - & - & - & $\begin{array}{c}29,90 \pm \\
5,70 \\
\end{array}$ & - & $\begin{array}{c}55,80 \pm \\
7,10 \\
\end{array}$ \\
\hline & & $C_{v}$ & 48,70 & - & - & - & - & 50,90 & - & 48,90 \\
\hline
\end{tabular}

Содержание белка и липидов в органах и тканях амфибий старшего возраста приближается либо достигает уровня показателей животных из биотопов р. Желтая, что свидетельствует об адаптации животных при выживании в этих условиях. Этому способствует увеличение уровня белка в легких, сердце, почках, селезенке и печени, а также 
гликогена в коже. Наиболее сильно проявляется влияние отходов предприятий по добыче и переработке урановой руды на амфибий из биотопов водоема хвостохранилища $\mathrm{P}$, в составе популяции которых отсутствуют сеголетки и годовики. В период наступления половой зрелости (животных 2 лет) установлено снижение показателей белкового и липидного обмена не только в мышечной ткани, но и в печени при увеличении его уровня в коже, где углеводы выполняют защитную функцию. В дальнейшем уровень содержания белка в органах и тканях в процентном отношении увеличивается за счет снижения содержания липидов и гликогена в мышечной ткани при постепенном увеличении его запасов в печени и коже. У половозрелых животных 3-6 лет установлено увеличение содержания белка и липидов в большинстве органов и тканей, которое, однако, не достигает их уровня в органах и тканях амфибий из биотопов р. Желтая (кроме кожи, селезенки, почек и печени, что увеличивает резистентность этих органов).

Биохимические параметры органов и тканей озерной лягушки

Таблий 4 из водоема хвостохранилища шахты Ольховская (\% м. массы)

\begin{tabular}{|c|c|c|c|c|c|c|c|c|c|c|}
\hline \multirow{2}{*}{$\begin{array}{l}\text { Воз- } \\
\text { раст }\end{array}$} & \multirow{2}{*}{\begin{tabular}{|c|} 
Биохи- \\
мические \\
параметры \\
\end{tabular}} & \multirow{2}{*}{$\begin{array}{l}\text { Пока- } \\
\text { затели }\end{array}$} & \multicolumn{8}{|c|}{ Органы и ткани } \\
\hline & & & печень & почки & сердце & легкие & селезенка & мышщы & гонады & кожа \\
\hline \multirow{6}{*}{$1-2+$} & \multirow[t]{2}{*}{ белок } & $x \pm m$ & $8,60 \pm 0,42$ & $\begin{array}{c}13,80 \pm \\
1,64\end{array}$ & $\begin{array}{c}9,98 \pm \\
1,52\end{array}$ & $\begin{array}{c}19,80 \pm \\
3,08\end{array}$ & $\begin{array}{c}30,90 \pm \\
4,16\end{array}$ & $\begin{array}{c}9,10 \pm \\
0,92 \\
\end{array}$ & $\begin{array}{c}8,82 \pm \\
0,84\end{array}$ & $\begin{array}{c}12,30 \pm \\
2,80\end{array}$ \\
\hline & & $C_{v}$ & 48,72 & 37,12 & 54,92 & 40,60 & 55,18 & 38,42 & 53,24 & 56,80 \\
\hline & \multirow[t]{2}{*}{ липиды } & $x \pm m$ & $3,70 \pm 0,25$ & $\begin{array}{c}8,02 \pm \\
1,12\end{array}$ & $\begin{array}{c}10,20 \pm \\
0,84\end{array}$ & $\begin{array}{c}5,90 \pm \\
0,45\end{array}$ & $\begin{array}{c}3,80 \pm \\
0,16\end{array}$ & $\begin{array}{c}2,02 \pm \\
0,08\end{array}$ & $\begin{array}{c}4,08 \pm \\
0,14\end{array}$ & $\begin{array}{c}2,00 \pm \\
0,10\end{array}$ \\
\hline & & $C_{v}$ & 38,41 & 45,80 & 40,12 & 40,51 & 52,44 & 45,18 & 57,80 & 44,80 \\
\hline & \multirow[t]{2}{*}{ гликоген } & $x \pm m$ & $\begin{array}{c}200,20 \pm \\
10,16\end{array}$ & - & - & - & - & $\begin{array}{c}25,84 \pm \\
6,20 \\
\end{array}$ & - & $\begin{array}{c}30,60 \pm \\
5,20\end{array}$ \\
\hline & & $C_{v}$ & 50,40 & - & - & - & - & 50,40 & - & 40,60 \\
\hline \multirow{6}{*}{$3-4+$} & \multirow[t]{2}{*}{ белок } & $x \pm m$ & $12,14 \pm 3,12$ & $\begin{array}{c}16,12 \pm \\
2,40 \\
\end{array}$ & $\begin{array}{c}9,32 \pm \\
1,84 \\
\end{array}$ & $\begin{array}{c}12,72 \pm \\
3,12 \\
\end{array}$ & $\begin{array}{c}32,52 \pm \\
4,16 \\
\end{array}$ & $\begin{array}{c}9,40 \pm \\
1,86 \\
\end{array}$ & $\begin{array}{c}10,18 \pm \\
0,42 \\
\end{array}$ & $\begin{array}{c}12,38 \pm \\
1,55 \\
\end{array}$ \\
\hline & & $C_{v}$ & 26,16 & 28,50 & 30,52 & 28,46 & 42,18 & 26,17 & 35,12 & 20,18 \\
\hline & \multirow[t]{2}{*}{ липиды } & $x \pm m$ & $2,90 \pm 0,40$ & $\begin{array}{c}6,86 \pm \\
0,58 \\
\end{array}$ & $\begin{array}{c}8,12 \pm \\
0,52 \\
\end{array}$ & $\begin{array}{c}3,80 \pm \\
0,28 \\
\end{array}$ & $\begin{array}{c}2,02 \pm \\
0,11\end{array}$ & $\begin{array}{c}1,80 \pm \\
0,12 \\
\end{array}$ & $\begin{array}{c}5,22 \pm \\
0,42 \\
\end{array}$ & $\begin{array}{c}1,08 \pm \\
0,11 \\
\end{array}$ \\
\hline & & $C_{v}$ & 35,18 & 39,72 & 36,12 & 35,16 & 59,90 & 45,17 & 56,18 & 52,18 \\
\hline & \multirow[t]{2}{*}{ гликоген } & $x \pm m$ & $\begin{array}{c}205,18 \pm \\
15,20\end{array}$ & - & - & - & - & $\begin{array}{c}20,80 \pm \\
5,90\end{array}$ & - & $\begin{array}{c}55,40 \pm \\
5,60\end{array}$ \\
\hline & & $C_{v}$ & 50,40 & - & - & - & - & 40,60 & - & 40,20 \\
\hline \multirow{6}{*}{$5-6$} & \multirow[t]{2}{*}{ белок } & $x \pm m$ & $12,98 \pm 2,18$ & $\begin{array}{c}17,80 \pm \\
3,14\end{array}$ & $\begin{array}{c}11,84 \pm \\
0,98\end{array}$ & $\begin{array}{c}12,96 \pm \\
1,56\end{array}$ & $\begin{array}{c}32,80 \pm \\
4,80\end{array}$ & $\begin{array}{c}10,12 \pm \\
2,12\end{array}$ & $\begin{array}{c}12,44 \pm \\
0,76\end{array}$ & $\begin{array}{c}13,48 \pm \\
3,24\end{array}$ \\
\hline & & $C_{v}$ & 22,12 & 24,18 & 20,12 & 20,12 & 32,56 & 14,72 & 20,44 & 12,42 \\
\hline & \multirow[t]{2}{*}{ липиды } & $x \pm m$ & $4,60 \pm 0,32$ & $\begin{array}{c}5,80 \pm \\
0,72 \\
\end{array}$ & $\begin{array}{c}7,80 \pm \\
0,89 \\
\end{array}$ & $\begin{array}{c}6,98 \pm \\
0,46 \\
\end{array}$ & $\begin{array}{c}3,20 \pm \\
0,42\end{array}$ & $\begin{array}{c}2,00 \pm \\
0,10 \\
\end{array}$ & $\begin{array}{c}5,06 \pm \\
0,26 \\
\end{array}$ & $\begin{array}{c}2,28 \pm \\
0,14 \\
\end{array}$ \\
\hline & & $C_{v}$ & 36,82 & 40,18 & 30,17 & 30,12 & 42,70 & 32,17 & 42,12 & 54,12 \\
\hline & \multirow[t]{2}{*}{ гликоген } & $x \pm m$ & $\begin{array}{c}200,20 \pm \\
40,20\end{array}$ & - & - & - & - & $\begin{array}{c}22,00 \pm \\
5,90\end{array}$ & - & $\begin{array}{c}58,90 \pm \\
6,90 \\
\end{array}$ \\
\hline & & $C_{v}$ & 25,20 & - & - & - & - & 30,60 & - & 40,20 \\
\hline
\end{tabular}

В водоеме хвостохранилища шахты Ольховская животные младших возрастных групп характеризуются более высокими показателями содержания белка в коже, гонадах, мышечной ткани, селезенке, легких и сердце при более низком его содержании в печени и почках (табл. 4). У амфибий 1-2 лет наблюдается снижение уровня гликогена, что связано с увеличением энергетических расходов организма амфибий в этих условиях обитания. У амфибий 3-4 лет из водоема хвостохранилища шахты Ольховская и р. Желтая происходит увеличение содержания белка в сердце, легких, селезенке, мышечной ткани и коже при снижении его уровня в печени, почках и, что особенно 
важно, в гонадах. Наблюдается снижение содержания липидов и гликогена в печени и мышечной ткани, что связано со значительным расходованием энергии, необходимой для повышения резистентности организма амфибий.

Таблица 5

Биохимические параметры органов и тканей озерной лягушки

из водоема хвостохранилища шахты Новая г. Желтые Воды (\% м. массы)

\begin{tabular}{|c|c|c|c|c|c|c|c|c|c|c|}
\hline \multirow{2}{*}{$\begin{array}{l}\text { Bo3- } \\
\text { pact }\end{array}$} & \multirow{2}{*}{\begin{tabular}{|c|} 
Биохимические \\
параметры \\
\end{tabular}} & \multirow{2}{*}{$\begin{array}{l}\text { Пока- } \\
\text { затели }\end{array}$} & \multicolumn{8}{|c|}{ Органы и ткани } \\
\hline & & & печень & почки & сердще & легкие & селезенка & мышщы & гонады & кожа \\
\hline \multirow{6}{*}{$1-2+$} & \multirow[t]{2}{*}{ белок } & $x \pm m$ & $7,80 \pm 0,35$ & $\begin{array}{c}13,65 \pm \\
0,90\end{array}$ & $\begin{array}{c}8,65 \pm \\
0,90\end{array}$ & $\begin{array}{c}18,05 \pm \\
1,60\end{array}$ & $\begin{array}{c}29,90 \pm \\
3,12\end{array}$ & $8,05 \pm 0,72$ & $\begin{array}{c}6,90 \pm \\
0,56\end{array}$ & $\begin{array}{c}10,18 \pm \\
1,90\end{array}$ \\
\hline & & $C_{v}$ & 45,16 & 36,12 & 52,12 & 52,18 & 42,18 & 40,52 & 54,17 & 56,18 \\
\hline & \multirow[t]{2}{*}{ липиды } & $x \pm m$ & $2,90 \pm 0,45$ & $\begin{array}{c}7,68 \pm \\
0,88\end{array}$ & $\begin{array}{c}10,06 \pm \\
0,70\end{array}$ & $\begin{array}{c}4,15 \pm \\
0,18 \\
\end{array}$ & $3,40 \pm 0,25$ & $2,20 \pm 0,10$ & $\begin{array}{c}4,22 \pm \\
0,16\end{array}$ & $\begin{array}{c}1,88 \pm \\
0,21\end{array}$ \\
\hline & & $C_{v}$ & 33,18 & 50,18 & 42,30 & 51,14 & 55,18 & 38,90 & 59,90 & 50,24 \\
\hline & \multirow{2}{*}{ гликоген } & $x \pm m$ & $\begin{array}{c}180,80 \pm \\
20,40\end{array}$ & - & - & - & - & $\begin{array}{c}20,18 \pm \\
3,10\end{array}$ & - & $\begin{array}{c}70,60 \pm \\
10,10\end{array}$ \\
\hline & & $C_{v}$ & 30,72 & - & - & - & - & 20,20 & - & 25,90 \\
\hline \multirow{6}{*}{$3-4+$} & \multirow[t]{2}{*}{ белок } & $x \pm m$ & $15,18 \pm 2,90$ & $\begin{array}{c}16,50 \pm \\
4,90\end{array}$ & $\begin{array}{c}3,99 \pm \\
1,70\end{array}$ & $\begin{array}{c}13,65 \pm \\
2,92\end{array}$ & $\begin{array}{c}34,52 \pm \\
4,98\end{array}$ & $\begin{array}{c}10,15 \pm \\
2,18\end{array}$ & $\begin{array}{c}10,20 \pm \\
1,18\end{array}$ & $\begin{array}{c}13,10 \pm \\
2,90\end{array}$ \\
\hline & & $C_{v}$ & 21,18 & 19,42 & 20,14 & 18,30 & 29,90 & 16,52 & 18,70 & 20,70 \\
\hline & \multirow[t]{2}{*}{ липиды } & $x \pm m$ & $1,98 \pm 0,22$ & $\begin{array}{c}5,12 \pm \\
0,56\end{array}$ & $\begin{array}{c}5,12 \pm \\
0,42\end{array}$ & $\begin{array}{c}3,14 \pm \\
0,20\end{array}$ & $3,40 \pm 0,62$ & $1,70 \pm 0,12$ & $\begin{array}{c}4,90 \pm \\
0,17\end{array}$ & $\begin{array}{c}2,00 \pm \\
0,14 \\
\end{array}$ \\
\hline & & $C_{v}$ & 24,18 & 25,18 & 26,90 & 29,40 & 30,86 & 21,12 & 28,17 & 28,56 \\
\hline & \multirow[t]{2}{*}{ гликоген } & $x \pm m$ & $\begin{array}{c}190,40 \pm \\
20,40\end{array}$ & - & - & - & - & $\begin{array}{c}20,20 \pm \\
5,40\end{array}$ & - & $\begin{array}{c}80,90 \pm \\
10,40\end{array}$ \\
\hline & & $C_{v}$ & 25,20 & - & - & - & - & 10,18 & - & 18,90 \\
\hline \multirow{6}{*}{$5-6$} & \multirow[t]{2}{*}{ белок } & $x \pm m$ & $16,28 \pm 3,92$ & $\begin{array}{c}16,80 \pm \\
4,25\end{array}$ & $\begin{array}{c}10,42 \pm \\
3,12\end{array}$ & $\begin{array}{c}14,10 \pm \\
3,92\end{array}$ & $\begin{array}{c}34,80 \pm \\
3,70\end{array}$ & $\begin{array}{c}10,20 \pm \\
3,14\end{array}$ & $\begin{array}{c}12,90 \pm \\
2,16\end{array}$ & $\begin{array}{c}14,90 \pm \\
1,80\end{array}$ \\
\hline & & $C_{v}$ & 18,70 & 20,30 & 12,18 & 20,40 & 28,10 & 12,16 & 12,20 & 18,20 \\
\hline & \multirow[t]{2}{*}{ липиды } & $x \pm m$ & $4,88 \pm 0,16$ & $\begin{array}{c}7,80 \pm \\
0,52\end{array}$ & $\begin{array}{c}6,50 \pm \\
0,40\end{array}$ & $\begin{array}{c}24,28 \pm \\
3,16\end{array}$ & $\begin{array}{c}28,12 \pm \\
3,28\end{array}$ & $\begin{array}{c}16,12 \pm \\
1,40\end{array}$ & $\begin{array}{c}20,15 \pm \\
2,14\end{array}$ & $\begin{array}{c}21,18 \pm \\
0,82\end{array}$ \\
\hline & & $C_{v}$ & 20,24 & 26,10 & 18,12 & 24,28 & 28,12 & 16,12 & 20,15 & 21,18 \\
\hline & \multirow[t]{2}{*}{ гликоген } & $x \pm m$ & $\begin{array}{c}250,90 \pm \\
20,60\end{array}$ & - & - & - & - & $\begin{array}{c}12,40 \pm \\
3,20\end{array}$ & - & $\begin{array}{c}85,40 \pm \\
15,50\end{array}$ \\
\hline & & $C_{v}$ & 30,50 & - & - & - & - & 10,05 & - & 15,30 \\
\hline
\end{tabular}

Анализ биохимических показателей у амфибий из биотопов хвостохранилища $\mathrm{P}$ показывает увеличение у двухлетних особей гликогена в коже, что, очевидно, связано с защитной функцией углеводов. В то же время снижение его количества в мышечной ткани и печени связано с увеличением его расходования для пополнения энергетических запасов организма. Это сопровождается также значительным расходованием липидов, необходимых для повышения резистентности организма животных (см. табл. 5).

Происходящее затем у амфибий старших возрастных групп увеличение белка и липидов в большинстве органов и тканей свидетельствует об определенной стабилизации метаболизма и некотором уровне адаптации амфибий к факторам загрязнения за счет увеличения резистентности их организма в период полового созревания. Этому способствует значительное расходование энергии углеводов и липидов органов и тканей.

\section{Выводы}

Исследование биохимических параметров организма фонового вида амфибий Приднепровского региона - озерной лягушки из четырех водоемов с различным уровнем влияния поллютантов из отходов предприятий по добыче и переработке урановой руды определило изменение показателей в органах и тканях животных белка, липидов и углеводов с возрастом, а также уменьшение данных биохимических параметров ор- 
ганизма животных в зависимости от степени этого влияния. Значительное увеличение расходования энергии липидов и углеводов является одним из механизмов биохимической адаптации и способствует частичной адаптации амфибий в условиях влияния отходов предприятий этого вида горнодобывающей промышленности.

\section{Библиографические ссылки}

1. Антропогенные проблемы экологии / А. И. Кораблева, А. Г. Шапарь, Л. В. Гербильский, С. З. Полищук. - Д. : Проминь, 1997. - 147 с.

2. Клейненберг Е. С. К методике определения возраста амфибий / Е. С. Клейненберг, Э. М. Смирина // Зоологический журнал. - 1969. - Т. 48, вып. 7. - С. 1070-1094.

3. Лабораторные методы исследований в клинике / Под ред. В. В. Меньшикова. - М. : Медицина, 1987. - С. 215-219, 234-235.

4. Огаркова Н. В. Регіональний вимір екологічної безпеки України з урахуванням загроз виникнення техногенних і природних катастроф / Н. В. Огаркова, А. Б. Качинский, А. С. Степаненко // Серія “Екологічна безпека”. - 1996. - Вип. 2. - 74 с.

5. Практикум по биохимии / Под ред. Н. П. Мешковой, С. Е. Северина. - М. : МГУ, 1979. - 129 с.

6. Сидоров В. С. Методы выделения тонкослойной и газожидкостной хроматографии липидов рыб // В. С. Сидоров, Е. И. Лизенко, О. М. Большова // Типовые методики исследования продуктивности видов рыб в пределах их ареалов. - Вильнюс, 1981. - Т. 4. - С. 58-68.

7. Смирина Э. М. Особенности структуры костной ткани амфибий и рептилий и проблема определения их возраста / Автореф. дисс. ... канд. биол. наук. - М. : МГУ, 1976. - 24 с.

8. Amphibians breeding and climate change / A. R. Blaustein, L. K. Belden, D. H. Olson et al. // Conservation Biol. - 2001. - Vol. 15. - P. 1804-1809.

9. Linder G. Amphibian decline: an integrated analysis of multiple stressor effects // G. Linder, S. K. Krest, D. W. Sparling. - Setac Press, 2003. - 368 p.

10. Papadimitrion E. A. Expozure of the frog Rana ridibunda to coopper: impact on two biomarkers, lipid peroxidation and glutathione / E. A. Papadimitrion, N. S. Loumbourdis // Bulletin of Environmental Contamination and Toxicology. - 2002. - Vol 69, N 6. - P. 885-891.

Надійшла до редколегії 12.04.2009 